\title{
Transition of Women's Economic Activity to Contribute to Family Income as an Effect Of COVID-19
}

\author{
KARINA CONCEPCIÓN GONZÁLEZ HERRERA ${ }^{1}$, YULIANA BEATRIZ SOLÍS JIMÉNEZ², \\ STEPHANY GISELLE MARTÍN SÁNCHEZ ${ }^{3}$ \\ ${ }^{1}$ Administration Division, UNIVERSIDAD TECNOLOGICA METROPOLITANA, MÉXICO. \\ E-mail: karina.gonzalez@utmetropolitana.edu.mx \\ ${ }^{2}$ Master's Student, TECNOLOGICO NACIONAL DE MEXICO, INSTITUTO TECNOLOGICO DE MERIDA, MÉXICO \\ ${ }^{3}$ Master's Student, TECNOLOGICO NACIONAL DE MEXICO, INSTITUTO TECNOLOGICO DE MERIDA, MÉXICO.
}

\begin{abstract}
The family economy of women underwent a transit, which generated the closure of companies; the abovementioned had an impact on the conversion of economic activities that women carried out in their localities to contribute to the family income. Therefore, the objective of this document is to analyze the women's transition and economic contribution to family income throughout the Covid-19 pandemic for the establishment of economic activities that support the family economy. The results indicate that women who engaged in tourism activities, the major source of revenue for the town, went to businesses that were seeing a boom due to the use of social media or online sales; in addition, it was possible to identify the strong impact of the woman's role in the family economy, contributing with more than $50 \%$ of the income. The foregoing will allow the generation of action proposals aimed at women to strengthen the virtual commercial scenario used in the pandemic for the constant and growing circulation of businesses, as well as the sale of their products and services.
\end{abstract}

Keywords: Economy; Family economy; Family income.

JEL Classification: D12, D13, R23. 


\title{
Transición de la actividad económica de las mujeres para la contribución en el ingreso familiar como efecto de la Covid-19
}

\author{
KARINA CONCEPCIÓN GONZÁLEZ HERRERA ${ }^{1}$, YULIANA BEATRIZ SOLÍS JIMÉNEZ², \\ STEPHANY GISELLE MARTÍN SÁNCHEZ ${ }^{3}$ \\ ${ }^{1}$ Administration Division, UNIVERSIDAD TECNOLOGICA METROPOLITANA, MÉXICO. \\ E-mail: karina.gonzalez@utmetropolitana.edu.mx
}

${ }^{2}$ Master's Student, TECNOLOGICO NACIONAL DE MEXICO, INSTITUTO TECNOLOGICO DE MERIDA, MÉXICO

${ }^{3}$ Master's Student, TECNOLOGICO NACIONAL DE MEXICO, INSTITUTO TECNOLOGICO DE MERIDA, MÉXICO.

\begin{abstract}
RESUMEN
La economía familiar de las mujeres sufrió un tránsito, lo cual generó el cierre de empresas; lo anterior incidió en la conversión de las actividades económicas que las mujeres desempeñaban en sus localidades para contribuir en el ingreso familiar. Por esto, el presente documento tiene por objetivo analizar la transición y contribución económica de las mujeres en la pandemia del Covid-19 en el ingreso familiar para el establecimiento de las actividades económicas que respaldan la economía familiar. Se obtuvo como resultados que las mujeres que realizaban actividades asociadas al turismo como fuente principal de ingresos de la localidad, transitó al comercio que presentó un auge debido a la utilización de las redes sociales o venta en línea para el comercio de estos; además se pudo identificar la fuerte contribución económica de la mujer a la economía familiar con más del 50\% de los ingresos. Lo anterior permitirá generar propuestas de acción encaminadas hacia las mujeres para fortalecer el escenario comercial virtual utilizado en la pandemia para la circulación constante y creciente del comercio de estas de los productos o servicios generados.
\end{abstract}

Palabras clave: Economía; Economía familiar; Ingreso familiar.

Clasificación JEL: D12, D13, R23. 


\section{Introduction}

As a result of the COVID-19 pandemic, there was an unfavorable impact on the incorporation status and working condition of women in Latin America and the Caribbean, which caused a decrease of more than ten years of their labor market integration (Economic Commission for Latin America and the Caribbean [ECLAC], 2021), estimating for 2020, the unemployment rate for women was $22.2 \%$ with respect to 2019 , which would represent a variation of $12.6 \%$ in the mentioned year. In 2020 , women presented a female employment rate of $46 \%$, with a decrease of $6 \%$ compared to the previous year.

At an international level, the practices of inequality among women are evident, despite the fact that the economic context is complicated by the current acute crisis and the lack of public policies focused on vulnerable women and the feminization of poverty. That is, "the needs of women who have endured the struggle of complex problems of violence, economic crisis, health vulnerability, lack of concern from public institutions, among others" (Oller \& Tornay, 2016, p. 246). In Mexico, the needs presented by women are associated with the lack of opportunities, inequity, violence, ignorance, poverty, and avoidable deaths, and other notable issues that continue to impact Mexican women. However, "the growing participation of women in the social, economic, political and cultural life of our country has been parallel to a substantial improvement in its demographic indicators, particularly in urban areas" (Moctezuma et al., 2014, p. 119).

On the other hand, the statistics carried out in Mexico indicate that out of 92.5 million inhabitants, $53.3 \%$ are women, and $46.7 \%$ are men. It is worth mentioning that 66.8 million (72.2\%) carry out activities for the market and production for self-consumption, and 91.2 million people (98.6\%) perform labor classified as unpaid domestic work. Regarding those who perform household work, $53.9 \%$ is composed of the female population and the remainder, 46.1\%, is male" (Institute of Geography and Statistics [INEGI], 2018, p. 106-107).

The needs faced by Yucatecan families as a result of the Covid-19 pandemic were reflected in the economic and social aspects, since staying at home to carry out daily activities and the performance of company tasks (home office) complicated the continuity of labor; however, those family members who worked and were in charge of businesses had to close due to the contingency, giving way to the single opening of only essential businesses. This had a direct influence on the definitive closing of the companies and on the unemployment of the population, among them women workers.

In Yucatán, according to the Ministry of Economy (2020), 48.3\% are women who represent the Economically Active Population (EAP). Therefore, the remaining $51.7 \%$ have not used their knowledge and skills due to the lack of promotion of economic activities; also, it should be noted that the document was conducted in Celestún, a municipality whose predominant economic activities are fishing, salt exploitation, tourism, and trade, with greater participation of tourism in the economy of the area.

The objective of the present study is to analyze the transition and economic contribution of women in the family income during the Covid-19 pandemic in order to establish the economic activities that support the family economy. Women in Mexico and in Yucatan have great importance for the social and economic development of the environment of a locality or community. Robles $(2021$, p. 2$)$ affirms that Mexican women have a relevant role in the economic development of the country in different factors such as "the generation of wealth and contribution to the GDP of the region. Equity boosts the productivity of countries, innovation and competitiveness, increases economic diversification and income equality, among other positive results". This makes it possible to assess the role of women in the family economy of the municipality of Celestún, in Yucatán, the object of this study. 


\section{Literature Review}

\subsection{The women's role in economic activities}

The classical theory of management arose in the industrial revolution to establish the standards of control in the face of the growth of activities in the industry, represented by Fayol, established the systems for administrative behavior and the total organization for its study, indicating that management was a complex process and should be taught to top management. Women began to play an important role in their participation in the economy, according to Scott (2009), who emphasizes that the visibility of working women was perceived as a problem during the period of the industrial revolution since it was described as new, and to which it was necessary to find a way to solve. What was related to the problem represented femininity and its compatibility with paid work? With such an event, women were already participants in the economy of the time, which made them look different to society, which led them to live unfair circumstances: their salary was less than that of a man, they were offered a minor task load, and the fact that they received a salary caused conflicts; nevertheless, it was part of an advance towards the women's development who, with time, would obtain more opportunities to grow.

In 1911, women were included in different economic activities; however, they continued with wage and other rights inequality; however, it is transcendental to clarify that currently, women have had more active participation in companies, since Azcoitia (2020) mentions that companies have developed a more humanistic perspective for the achievement of institutional goals, which is why the female population has managed to advance in their introduction to the labor market, considering their abilities to manage their time intervals, prioritize their activities in an organized way, use their resources efficiently, leading them to increase a series of competencies appreciated by organizations, such as adaptability, compromise, planning, solidarity, and emotional intelligence. Women have grown at a business level because they are recognized for the skills they are able to perform efficiently in organizations, contributing to success in different work areas.

Women are committed to the work they do, which is considered to be a relevant factor, given that they have had the possibility of participating in activities throughout the history of development of organizations, Fernández (2020) explains that, over time, women have followed a traditionalist role in the family, specializing in household chores: cleaning, preparing food, caring for the children, taking care of the husband's needs, among others. It was not until the end of the 18th century, with the Industrial Revolution, that the female population began to enter the labor market. However, the circumstances were extremely unbalanced, with women earning lower wages than men and lacking several social rights. From the moment women began to work, they have not enjoyed equal employment opportunities compared to men, they received lower salaries, and the working conditions were different. Currently, this situation has changed as Pérez (2003, p. 1) states that:

According to OECD data between 1974 and 1986, the presence of women in executive and management positions rose from $15.9 \%$ to $34.5 \%$ in Canada; from $8.8 \%$ to $20 \%$ in Sweden; from $18.5 \%$ to $37 \%$ in the United States; and from $15 \%$ to $20 \%$ in the FRG. In the labor markets of Latin America, it is reaffirmed that women intervene to a lesser degree, compared to men; that is, they obtain less probability of occupying informal part-time jobs, the same way it has a lower productivity and compensation, sometimes, some women are dedicated to office jobs occupying a managerial or executive position, which is why the lowest rate of participation of women is obtained within industrial companies. At the end of 2017, women obtained for the first time "a participation rate of $50 \%$ until reaching $50.2 \%$, that is to say; the participation rate registered by women is 25 percentage points, compared to men who obtained $74.4 \%$ in the latest report data" (ILO, 2017, p. 39).

Participation has been increasing in relation to top corporate management positions, and this is an extremely important step for women because it demonstrates that they have the intelligence and capacity to lead work teams for the effective management of organizations. As Marchionni (2019) states, in the Latin American labor market, the participation of women is lower than those belonging 
to the male population, producing a scenario where it is more feasible for them to occupy non-formal, partial jobs, resulting in lower performance and, therefore, lower salaries, being underrepresented in managerial or high management positions.

It is still difficult for women to position themselves in companies, despite the progress they have made in recent years. Women's work is a task that is not fully recognized and valued by society since women who are not educated are willing to dedicate themselves to domestic work, but this represents a flow of income that allows them to contribute to the family economy.

\subsection{Women's context in economic activities}

According to the Economic Commission for Latin America [CEPAL] (2019) the poverty trend registered since 2015 in Latin America has obtained an increase of $30.1 \%$ of the county's population finding themselves below the poverty line in 2018. Likewise, $10.7 \%$ subsists in a position of extreme poverty, while the rates would increase to $30.8 \%$ and $11.5 \%$ proportionally, in 2019 , this data reflects the increase in poverty that has been registered during the 3 years mentioned to take into account what families experience in this world. According to the National Occupation and Employment Survey (ENOE), in the second quarter of $2019,60.2 \%$ is conformed of the economically active population (EAP), while $39.8 \%$ constitutes the fraction of the non-economically active population (NEAP), as reported by the (National Institute of Statistics and Geography [INEGI], 2019).

In the country, according to employment income, a decrease of $2.5 \%$ was identified between 2019's fourth quarter and 2020's fourth quarter. This means that it increased labor poverty (proportion of the population with a wage income lower than the valuation of the basic food basket) from $37.3 \%$ to $40.7 \%$ in this period (National Council for the Evaluation of Social Development Policy [CONEVAL], 2021, p. 1), statistics that are associated with the presence of the pandemic. For the (National Institute of Statistics and Geography [INEGI], 2020), Yucatán has 2,320,898 inhabitants, and $50.9 \%$ is represented by the female gender. The EAP data is 1,160,284, being the EAP-Employed the $98.8 \%$ (1146809).

The Official Gazette (2019) states that in Yucatan, 5.7\% of employed women did not receive any (economic) support for their work, compared to $2.2 \%$ of men who are in the same situation; In other words, a difference of $2.6 \%$ is obtained with an inclination to the female gender. The state of Yucatan is in 16th place out of the 31 states, and Mexico City, which has the highest rate of women who are not paid, a situation that further limits the family economy.

The EAP-employed of women is equivalent to $39.6 \%$ regarding the municipality of Celestun. This is integrated by an EAP of 3005 and a female EAP-employed of $30 \%(900)$ of a population equivalent to 8389 inhabitants, where $49.5 \%$ of the population is female.

According to the INEGI portal (2020) in Celestún, the population (12 years and older employed) performs the following most representative activities:

1. Merchants, sales employees, and sales agents (232) - $25.8 \%$

2. Workers in personal services and surveillance (186) - $20.7 \%$

3. Artisanal workers and other trades (118) - 13.2\%

4. Elementary and support workers (200) - $22.3 \%$

There is a greater representation of women in commerce than in elementary and support activities. It should be noted that commerce activities are associated with tourism, and elementary, and support activities are associated with fishing (these are two of the main economic activities in Celestun).

Table 1 shows that $93.3 \%$ and $93.2 \%$ of the companies registered in Yucatan and Merida are micro, respectively, and in Celestun, $87.4 \%$ are of the same size, with $11.1 \%$ of medium-sized companies dedicated to commerce and fishing activities. 
Table 1 Size and number of companies at the level in the economies.

\begin{tabular}{|l|c|c|c|}
\hline \multicolumn{1}{|c|}{ Size of the company } & Mexico & Yucatan & Celestun \\
\hline Micro (0 a 10) & $5,146,586$ & 121,215 & 664 \\
\hline Small (11 a 50) & 299,837 & 7,384 & 84 \\
\hline Medium (51 a 100) & 32,898 & 706 & 7 \\
\hline Large (Más de 100) & 36,542 & 713 & 0 \\
\hline
\end{tabular}

Source: Data taken from (National Institute of Statistics and Geography [INEGI], 2019)

\section{Methodology}

For the present study, a mixed research method was used, where the conducted research instruments complemented this, a questionnaire (quantitative research approach) and an observation guide (qualitative research approach) were utilized. For Pereira (2011, p. 17), the use of more than one research method allows one to know, understand, interpret, and analyze the phenomenon, even more with the intervention of the human element in various circumstances. The research with the mixed method (MM) allows both instruments to overcome the limitations of both under each approach, which stimulates and strengthens the authenticity of the interpretation of the results (Hamui-Sutton, 2013 , p. 212). For research, the use of the mixed method of research is relevant, which is considered by Guerrero-Castañeda, et al. (2016), stating that:

The mixed design or mixed-method involves using quantitative and qualitative strategies in the same research project; they are also called mixed methods, combined methods, combined designs, and even triangulation of methods; it involves using quantitative and qualitative tools, it implies the discussion of the method, starting with the present discussion on the issue of knowledge generation before thinking about the method. (p. 245).

For this purpose, it was established that the profile of the women subjects of the study is associated with the EAP-Occupied of the municipality of Celestun in Yucatan. The sample was determined based on the formula for finite and known populations, for the application of the instrument, with a response of 173 instruments.

$$
\text { Formula: } n=\frac{\sigma^{2} \mathrm{NPq}}{e^{2}(N-1)+\sigma^{2} P q}=168.35=169
$$

Where:

$\sigma^{2}=$ Confidence coefficient $=(1.81)^{2}=3.28$

$\mathrm{N}=$ Universe or population $=900$

$\mathrm{P}=$ Probability favor $=0.5$

$q=$ Probability against $=0.5$

$e^{2}=$ estimation error $=(0.07)^{2}=0.0049$

The observation guide was randomly addressed to the women (1 out of 3 ) who responded to the first instrument (the questionnaire) in a random manner and by convenience, for a total of 75 , for the validation of the conditions in which the work is performed.

\section{Results and Discussion}

In relation to age, marital status, and income generated, the following profile of working women in the municipality of Celestun was obtained (table 2).

It can be observed that women, through the economic activities they perform and associated with the level of education they have, manage to obtain incomes of up to 2 minimum wages (SM), ranging from $\$ 4,307.8$ to $\$ 8,615.4$ pesos; however, there is a greater representation of $1 \mathrm{SM}$. With a married marital status and a middle school education, this is the profile of the women in the town of Celestun, Yucatan. 
Table 2 Profile of women who carry out an economic activity in Celestún.

\begin{tabular}{|c|c|c|c|c|c|}
\hline Profile & $>$ Representative & Percentage & Arithmetic mean & Asymmetry & Curtosis \\
\hline Age & $\begin{array}{c}20 \text { to } 24 \text { years } \\
\text { old }\end{array}$ & $22.7 \%$ & $\begin{array}{c}30 \text { to } 34 \text { years old } \\
(4.58)\end{array}$ & 0.600 & -0.640 \\
\hline Marital status & Married & $44.2 \%$ & Married (2.39) & 0.927 & -0.306 \\
\hline $\begin{array}{c}\text { Education } \\
\text { level }\end{array}$ & Middle school & $32.0 \%$ & $\begin{array}{c}\text { Middle school } \\
(2.63)\end{array}$ & 0.334 & -0.563 \\
\hline $\begin{array}{c}\text { Income } \\
\text { generated }\end{array}$ & $\$ 1$ to $\$ 4,307.7$ & $62.2 \%$ & $\begin{array}{c}\$ 4,307.8 \text { to } \\
\$ 8,615.4(1.97)\end{array}$ & 0.900 & 0.738 \\
\hline
\end{tabular}

Source: own elaboration.

The women in the community carry out different economic activities, such as commerce online and in physical stores (60\%), $27 \%$ work in economic kitchens, $6 \%$ as warehousemen where they are in charge of seafood filleting and fleshing, $2 \%$ in sewing, $2 \%$ as hairdressers, $1 \%$ in veterinary medicine, counter clerks and cyber stationery. Of the mentioned activities, most agree that they do not have a fixed schedule (66\%), 19\% work from 7 am to $3 \mathrm{pm}, 2 \%$ from $1 \mathrm{pm}$ to $9 \mathrm{pm}, 1 \%$ from 10 am to $6 \mathrm{pm}$. In the performance of economic activities, women present and identify as their main obstacles the existence of a scarce number of companies (45\%), the low salaries in the existing organizations $(30 \%)$, the difficulty to leave the municipality and perform their economic activities (8\%), the difficulty of public transportation (5\%), and other obstacles (13\%) (Figure 1).

Figure 1 Main obstacles identified in the municipality for their labor integration.

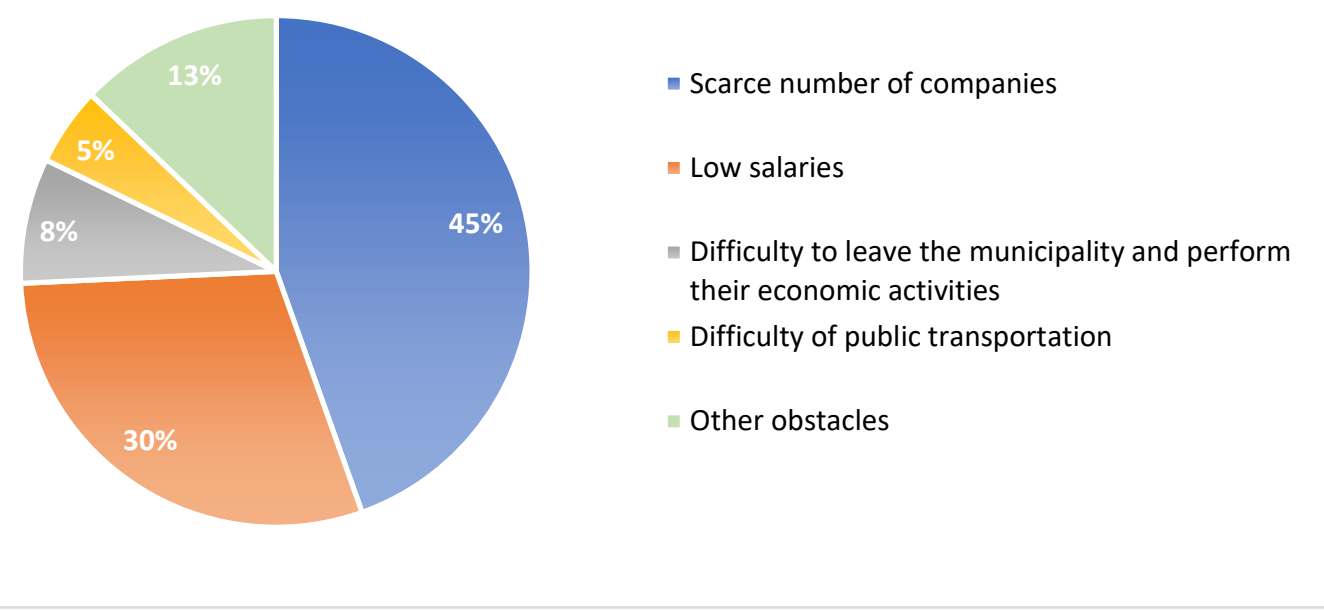

Source: self-made

The community's women consider that the following limitations are present: competition (38\%), the current low sales due to Covid-19 (19\%), they mention that there are few spaces in the municipality to offer their products or services (12\%), the purchase of products or services at low prices, mainly in seafood stores ( $9 \%)$, the remaining percentage considers the working hours to be limited (5\%), and the fact of offering products at low cost before they deteriorate (5\%). (Figure 2).

In women's opinion, the competition created in the municipality is mostly economic competition (49\%), which refers to the continuous raising and lowering of prices, it is considered unfavorable (16\%), others think that it does not allow other businesses to grow (12\%), and it is also mentioned that it is unfair (7\%). (Figure 3) 
Figure 2 Limitations presented in the place where the products or services are offered

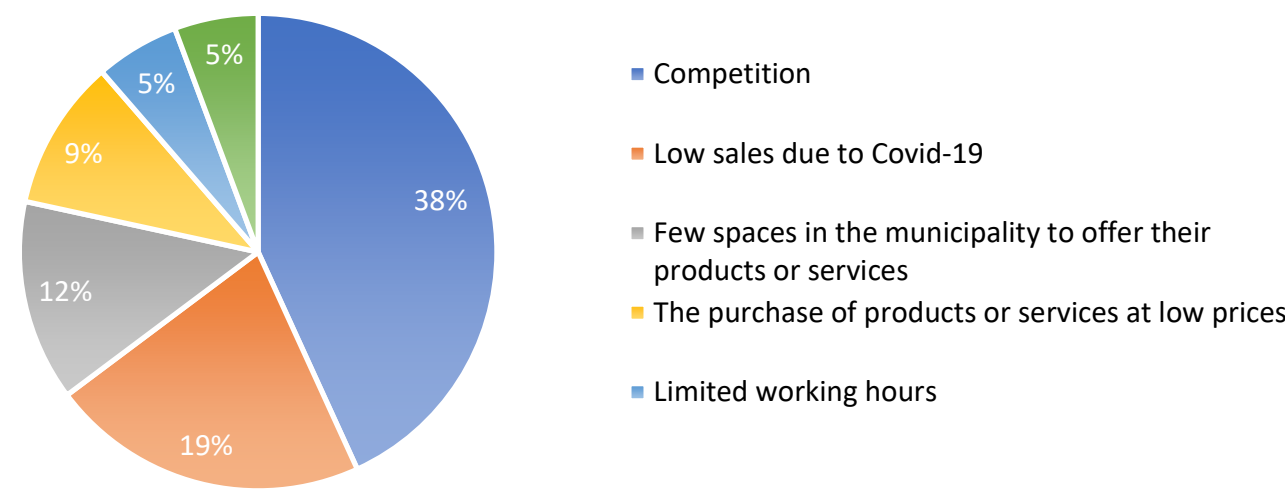

Source: self-made

Figure 3 Opinions regarding the competition generated in the municipality.

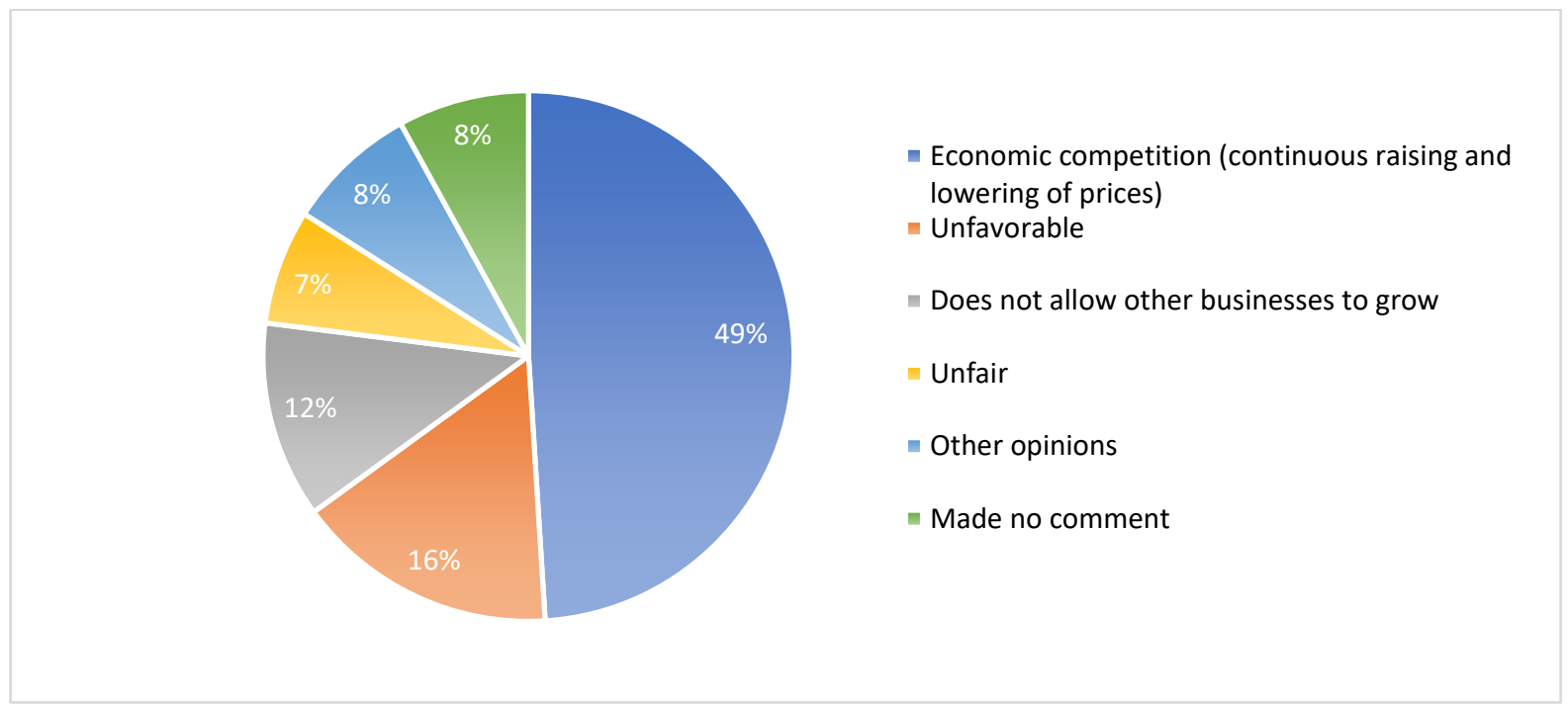

Source: self-made

A factor that does not favor women in carrying out their economic activities is that, according to the data collected, most of them do not participate in training processes (62\%), only $13 \%$ have done so 1 to 2 times, which means that the higher the frequency and attendance of training courses, the fewer the number of participants. The observation guide showed that the companies where the women work maintain hygienic conditions in the following manner:

1. They keep their workplaces clean and tidy, as well as the implementation of hygienic measures before Covid-19,

2. Currently, more than $77 \%$ have only a bottle of sanitizer or anti-bacterial gel and window protectors (56\%).

3. The environment is adequate due to the fact that $99 \%$ say that the work environment is pleasant and with leadership since $96 \%$ were found to be the leader.

4. The processes for services and products are carried out under control and care to ensure their final quality, under the care of continuous hygiene (96\%),

5. Products are stored and tidied up after processing. 


\subsection{Discussion}

In comparison with the study conducted in the municipality of Celestun called "participation of women in the socio-economic practices of the ecotourism project of the Ria Celestun Biosphere Reserve" in 2015 , Casais et al. $(2015$, p. 29) states that it is admitted that the female population of the municipality of Celestún is actively and decisively involved in the economic progress of the area, however, it is inevitable to improve the level of education and ecological reflection for the preservation of the ecosystem that allows continuing with the economic growth of the community without being harmed. This action has managed to transform the traditionalist perspective that rules the role of women at home and in the community, achieving a vision that leads them to get an occupation to obtain an economic benefit. Likewise, these actions have allowed her to understand the insufficiency of help from agents in the governmental sectors, setting aside activities that help to diminish this gap.

However, the study was carried out prior to the pandemic, when hygiene conditions were not yet required and necessary. As of today and with the data collected, it can be mentioned that local women workers have made the cleaning and hygiene of spaces a fundamental part of their activities, as well as to reach $100 \%$ compliance with current regulations on the use of disinfectant and sanitizing gel in the workspace, required by $23 \%$ of the companies studied.

It was found that the women of Celestún are working because they seek to provide greater economic support to improve their living conditions and those of their families; the women are engaged in different jobs within the community, such as, for example, as warehouse workers that complement fishing, and the production and sale of handicrafts that are integrated into the tourism sector. It should also be noted that women have greater participation in the trade of various items online and in physical grocery or clothing stores. In substitution to the most relevant and representative activity of the municipality, tourism, making the required transition to online commerce as an option for labor continuity and contribution to the family economy, it is then that it can be mentioned that the women under study contribute more than $50 \%$ of the family income.

Regarding the income of the Employed EAP in 2015 for CONAPO (2016), it was up to 2 SM. It is observed that with respect to the results obtained, that the average income of women is below $0.03 \%$, and in relation to the highest representativeness this the data reflects that it is $>30 \%$ of the income equivalent to $1 \mathrm{SM}$, in the same way, it allows to highlight that the salary of women for the economic activity carried out is lower than that of men. It is highlighted that more than $70 \%$ of the women interviewed carry out activities informally, which compared to the state data reported in Yucatan equivalent to the $58.6 \%$ reported by the ENOE (INEGI, 2021), the identified labor informality is $>11.4 \%$.

\section{Conclusion}

It is worth mentioning that since the pandemic, women have been integrated into the work activities that complement their household responsibilities. This leads to a new culture that will be transmitted to future generations, where both men and women carry out household and economic activities, which is not present with high intensity in the municipalities of Yucatan because there is still a prevalence of male superiority as the provider of family income (since women themselves perceive the husband or man of the house as the representative of the household, despite the fact that in some situations it is the woman who earns more income and is responsible for covering the needs of the children, among other things). Likewise, it was found that women in the municipality stand out for their dynamism, where they still do not perceive in an attractive way the participation in social activities or projects, due to the time they will invest in the activities to be carried out, which stimulate their integration because it is considered outside the profile of local women, where it was identified that they are involved in fishing activities, filleting, work in warehouses, among others.

The training required by the women of Celestun should be focused first and foremost on practice since based on academic training (primarily secondary school), they can be guided in a timely manner and with better results than with a broad theoretical foundation, which could be far from a complete understanding of the subject. This does not mean eliminating information supported by literature. It 
means that this information should be included, but with less burden for the correct and pertinent instruction of the female population in the use of social networks and the spaces available online for the trade of their products.

\section{References}

1. Azcoitia, J. (January 17, 2020). The role of women in organizations. Retrieved on May 26, 2021, from Armstrong:

https://www.armstrong.com.mx/2020/01/el-papel-de-las-mujeres-en-las-organizaciones-2/

2. Casais M., D., Cortés C., RL, Martín M., M. Pinkus R., M., Pinkus R., M. (2015): "Participation of Women in Socioeconomic Practices of the Project of Ecotourism of the Ría Celestún Biosphere Reserve". In Peninsula journal [online] 2015, X (July-December. Http://www.redalyc.org/articulo.oa?id=358340293001

3. Consejo Nacional de Población. (2016). Índice de Marginación por localidad 1995-2015. Datos abiertos del índice de marginación. Obtenido de Gobierno de México: http://www.conapo.gob.mx/es/CONAPO/Datos_Abiertos_del_Indice_de_Marginacion

4. Economic Commission for Latin America [ECLAC]. (December 2019). Social Panorama of Latin America 2019. Retrieved on June 1, 2021, from the Economic Commission for Latin America: https://repositorio.cepal.org/bitstream/handle/11362/44969/5/S1901133_es.pdf

5. Economic Commission for Latin America and the Caribbean [ECLAC]. (2021). The economic autonomy of women in sustainable recovery and with equality $\mathrm{d}$. Economic Commission for Latin America and the Caribbean (ECLAC). https://repositorio.cepal.org/bitstream/handle/11362/46633/5/S2000740_es.pdf

6. National Council for Political Evaluation of Social Development [CONEVAL]. (2021). INDEX OF THE LABOR TREND OF POVERTY (ITLP) TO THE FOURTH QUARTER OF 2020. DIRECTORATE OF INFORMATION AND SOCIAL COMMUNICATION (page 26). Mexico: CONEVAL. https://www.coneval.org.mx/SalaPrensa/Comunicadosprensa/Documents/2021/COMUNICADO_ 02_ITLP_4to_TRIMESTRE_2020.pdf

7. Official Gazette of the Government of the State of Yucatán. (December 12, 2019). SPECIAL PROGRAMS, GENDER EQUALITY, OPPORTUNITIES AND NON-DISCRIMINATION. -SUMARIOGOVERNMENT OF THE STATE PODER EXECUTIVO, 054 (34), 104. http://yucatan.gob.mx/docs/diario_oficial/diarios/2019/2019-12-12_8.pdf

8. Fernández, A. (June 14, 2020). Women in the world of work. The vanguard. https://www.lavanguardia.com/vida/junior-report/20180129/44376132844/mujeres-mundolaboral.html\#: :text=A\%20finales\%20del\%20siglo\%20XVIII,ten\%C3\%ADan\%20los \% 20same\% 20right\% 20labor.

9. Guerrero-Castañeda, R., Lenise do Prado, M. \& Ojeda-Vargas, M. (2016). Epistemological critical reflection on mixed methods in nursing research. University Nursing, 13(4), 246-248. Doi: http://dx.doi.org/10.1016/j.reu.2016.09.001

10. Hamui-Sutton, A. (2013). An approach to mixed methods of research in medical education. Research in Medical Education, 2 (8), 211-216. https://www.redalyc.org/pdf/3497/349733226006.pdf

11.National Institute of Statistics and Geography [INEGI]. (2019). National Statistical Directory of Economic Units [DENUE]. INEGI: https://www.inegi.org.mx/app/mapa/denue/default.aspx

12. National Institute of Statistics and Geography [INEGI]. (2019). Result of the National Survey of Occupation and Employment. Figures during the second quarter of 2019. https://www.inegi.org.mx/contenidos/saladeprensa/boletines/2019/enoe_ie/enoe_ie2019_08.p df 
13. National Institute of Statistics and Geography [INEGI]. (2021). Encuesta Nacional de Ocupación y Empleo. https://www.inegi.org.mx/programas/enoe/15ymas/\#Tabulados

14.Institute of Geography and Statistics [INEGI]. (2018). Women and Men in Mexico 2018. Mexico: INEGI. http://cedoc.inmujeres.gob.mx/documentos_download/MHM_2018.pdf

15. National Institute of Statistics and Geography [INEGI]. (2019). Result of the National Survey of Occupation and Employment. Figures during the second quarter of 2019. https://www.inegi.org.mx/contenidos/saladeprensa/boletines/2019/enoe_ie/enoe_ie2019_08.p df

16. National Institute of Statistics and Geography [INEGI]. (2020). Population and Housing Census 2020. Microdata. https://inegi.org.mx/programas/ccpv/2020/\#Microdatos

17. Marchionni, M. (February 17, 2019). Gender gaps in Latin America. A state of affairs. Andean Development Corporation. SCIOTECA: https://scioteca.caf.com/bitstream/handle/123456789/1401/Brechas\%20de\%20genero\%20en\%2 0America\%20Latina.\%20Un\%20estado\%20de\%20situacion.pdf?sequence=5\&isAllowed=y

18. Moctezuma, N. D., Narro, R. J., \& Orozco, H. L. (January-April 2014). Women in Mexico: inequity, poverty and violence. Mexican Journal of Political and Social Sciences, 59 (220), 117 - 146. doi: https: //doi.org/10.1016/S0185-1918 (14) 70803-70IT. (2017). Panorama Laboral 2017 América Latina y el Caribe (Primera Edición ed.). Perú: Oficina Regional para América Latina y el Caribe. https://www.ilo.org/wcmsp5/groups/public/---americas/---rolima/documents/publication/wcms_613957.pdf

19.International Labor Organization [ILO]. (2017). 2017 Labor Overview Latin America and the Caribbean (First Edition ed.). Peru: Regional Office for Latin America and the Caribbean. https://www.ilo.org/wcmsp5/groups/public/---americas/---rolima/documents/publication/wcms_613957.pdf

20.Oller, A. M., \& Tornay, M.,. (2016). COMMUNICATION, JOURNALISM AND GENDER. A LOOK FROM IBEROAMERICA. In X. Cabrera, A. Carratalá, R. P. Chavero, G. V. Guarinos, M. E. Navarro, D. T. Núñez,. A. Zaptsi, Communication, Journalism and Gender. A look from Latin America (pp. 229 250). Seville: Egregius.

https://idus.us.es/bitstream/handle/11441/48548/periodismoygenero.pdf?sequence=1\&isAllowe $\mathrm{d}=\mathrm{y}$

21.Pereira, P. Z. (2011). Mixed method designs in educational research: A concrete experience. Educare Electronic Magazine, XV (1), 15-29. https://www.redalyc.org/pdf/1941/194118804003.pdf

22.Pérez, J. (2003). The role of women in the company. Bizkaia: https://www.bizkaia.eus/Home2/Archivos/DPTO1/Temas/Pdf/ca_mujerempresa.pdf?hash=f2a83 b8aa85967bcd7b867cd8968ac6e\&redirigido=1Robles, V. . (8 de Marzo de 2021). El impacto de la mujer en la economía mexicana: la inclusión y el despegue financiero. Forbes, págs. 1-2. https://www.forbes.com.mx/red-forbes-el-impacto-de-la-mujer-en-la-economia-mexicana-lainclusion-y-el-despegue-financiero/

23.Robles, V.. (March 8, 2021). The impact of women on the Mexican economy: inclusion and financial take-off. Forbes, pp. 1-2. https://www.forbes.com.mx/red-forbes-el-impacto-de-la-mujer-en-laeconomia-mexicana-la-inclusion-y-el-despegue-financiero/

24.Ministry of Economy. (2020). Celestún, Municipality. Data México: https://datamexico.org/es/profile/geo/celestun?totalGenderSelector=genderOption 